\title{
IMPLEMENTASI PEMBANGUNAN BERKELANJUTAN DALAM MENGATASI KEMISKINAN MELALUI KERJA SAMA INTERNASIONAL DAERAH
}

\author{
Sri Issundari dan Yanyan M. Yani \\ Jurusan Ilmu Hubungan Internasional \\ Fakultas Ilmu Sosial dan Ilmu Politik \\ Universitas Pembangunan Nasional "Veteran" Yogyakarta \\ Jurusan Ilmu Hubungan Internasional \\ Fakultas Ilmu Sosial dan Ilmu Politik \\ Universitas Padjadjaran \\ Email:sri.issundari@upnyk.ac.id \& y.mochamad@unpad.ac.id
}

\begin{abstract}
ABSTRAK
Globalisasi mendorong setiap daerah berkompetisi melaksanakan pembangunan. Pembangunan menjadi salah satu strategi daerah mengurangi ketimpangan dan kemiskinan. Berbagai upaya dilakukan pemerintah daerah untuk membuka jalan mengatasi kemiskinan. Kerja sama internasional daerah merupakan salah satu strategi mengatasi kemiskinan sekaligus mengurangi ketergantungan kepada pendanaan pusat. Kerja sama internasional daerah juga menjadi sarana untuk mengembangkan potensi daerah. Tulisan ini bertujuan mengamati kerja sama internasional daerah dalam upaya mengatasi kemiskinan dalam kerangka pembangunan berkelanjutan. Dengan mengambil studi kasus kerja sama internasional Yogyakarta dan Gyeongsangbukdo Korea Selatan di desa Ponjong Gunung Kidul maka penelitian ini menyimpulkan bahwa kerja sama internasional daerah merupakan salah satu cara mencapai pembangunan berkelanjutan melalui pengembangan potensi desa. Melalui transfer ilmu pengetahuan, pemberdayaan masyarakat, dan pengembangan fasilitas publik maka dapat membantu meningkatkan aktifitas perekonomian daerah secara berkelanjutan sekaligus sekaligus mendukung pembangunan nasional.
\end{abstract}

Kata kunci : pembangunan berkelanjutan-kemiskinan-kerja sama internasional-daerah

\section{ABSTRACT}

Globalization encourages every region to compete for development. Development became one of the regional strategies to reduce inequality and poverty. Various efforts were made by local governments to pave the way to overcome poverty. Regional international cooperation is one of the strategies to overcome poverty while reducing reliance on central funding. Regional international cooperation also becomes a means to develop regional potential. This paper aims to observe regional international cooperation to overcome poverty within the framework of sustainable development. By taking a case study of international cooperation of Yogyakarta and Gyeongsangbukdo South Korea in Ponjong Gunung Kidul village, this research concluded that regional international cooperation is one way of achieving sustainable development through the exploration of village potential. The transfer of science, community empowerment, and the development of public services can help increase regional economic activities sustainably while supporting national development.

Keyword : sustainable development-poverty-international cooperation-regional 


\section{PENDAHULUAN}

Ancaman kesenjangan dan kemiskinan merupakan salah satu persoalan mendasar pembangunan berkelanjutan. Peningkatan jumlah penduduk miskin menjadi tantangan pemerintah dalam melaksanakan progam kerja sehingga akan berdampak pada perlambatan pertumbuhan ekonomi.

Bahaya akan ancaman kemiskinan dan kelaparan menjadi perhatian PBB. Hal itu tercantum dalam dokumen Tujuan Pembangunan Berkelanjutan yang berjudul Transforming Our World: the 2030 Agenda for Sustainable Development pada tanggal 25 September 2015. Dalam pertemuan tersebut PBB secara tegas menguraikan bahwa mengatasi kemiskinan menjadi salah satu pilar utama pembangunan berkelanjutan. Strategi tersebut merupakan bagian dari Dokumen yang berisikan 17 Tujuan dan 169 Sasaran Tujuan pembangunan berkelanjutan (Sustainable Development Goals atau SDGs) yang berlaku mulai tahun 2016 hingga tahun 2030 (United Nations, n.d).

Daerah memiliki kontribusi yang besar dalam mendukung pencapaian pembangunan berkelanjutan dalam hal pengentasan kemiskinan. Keberadaan daerah secara tidak langsung menjadi titik sentral pelaksanaan pembangunan dan pengelolaan kearifan lokal. Meskipun tidak memiliki otoritas yang cukup besar dalam melakukan hubungan internasional, akan tetapi akses pemerintah daerah langsung berhubungan dengan masyarakat daerah. Keberhasilan pemerintah daerah dalam melaksanakan pembangunan akan berkontribusi secara langsung pada peningkatan kesejahteraan masyarakat secara nasional. Oleh karena itu pemerintah daerah perlu memiliki strategi yang efektif dalam mengatasi perangkap kemiskinan warganya.

Pembahasan mengenai strategi mengatasi kemiskinan dalam mendukung pembangunan berkelanjutan sebenarnya sudah banyak diangkat. Umumnya strategi mengatasi kemiskinan dimulai dari pembangunan fisik dan non fisik. Artikel yang mengangkat strategi pembangunan dalam mengatasi kemiskinan diantaranya dilakukan Trivelli et al. yang fokus pada strategi mengatasi kemiskinan melalui peningkatan investasi untuk pengembangan infrastruktur (Trivelli, Yancari, \& De los Ríos, 2009) dan pembangunan pedesaan (Andrews, 2004; Swastika \& Supriyatna, 2016). Pembangunan prasarana fisik seperti sekolah, pasar, jembatan, irigasi dipercaya sebagai salah satu media untuk memfasilitasi masyarakat agar mandiri dan mampu mengatasi kemiskinan. Strategi pengentasan kemiskinan tidak hanya berhenti pada pengambangan fisik, melainkan juga kepada non fisik seperti pengembangan program sosial (Swastika \& Supriyatna, 2016; Trivelli et al., 2009) dan juga pengembangan program pendidikan dasar (Andrews, 2004). Prioritas utama yang akan dicapai adalah peningkatan kualitas manusia baik dari sisi pendidikan, kesehatan, maupun ekonomi sehingga dapat membantu dirinya sendiri untuk keluar dari kemiskinan. Pengembangan sarana fisik dan non fisik menjadi perhatian pemerintah daerah dalam mendorong pertumbuhan ekonomi masyarakat. Dalam mengatasi kemiskinan, Mubangizi (2009) melihat dari aspek pemerintahan. Peningkatan fungsi pelayanan pemerintah juga penting untuk mempermudah 
masyarakat memperoleh akses informasi mengenai program-program pemerintah bagi masyarakat (Mubangizi, 2009).

Meskipun demikian perlu dicatat bahwa kegiatan tersebut sebagian besar berasal dari bantuan dana pemerintah pusat. Dengan demikian upaya pengentasan kemiskinan sangat ditentukan oleh kelancaran pendanaan program pemerintah pusat yang diturunkan ke daerah dengan catatan kondisi stabil bebas konflik (cnnindonesia.com, 2017). Disisi lain, daerah juga harus mencari cara lain agar tidak terlalu bergantung pada pendanaan dari pemerintah pusat. Pernyataan Menteri Dalam Negeri Tito Karnavian pada rapat kerja percepatan penyaluran dan pengelolaan dana desa di Palembang, Sumatera Selatan tanggal 28 Februari 2020 lalu menghimbau agar pemerintah daerah harus lebih kreatif, tidak hanya menerima bantuan pusat untuk meningkatkan pembangunan daerah (kompas.com, 2020) Artikel ini akan fokus pada upaya daerah dalam mengatasi kemiskinan melalui pendanaan dari luar negeri yaitu memanfaatkan kerja sama luar negeri. Kerja sama luar negeri memberikan alternatif cara bagi daerah untuk mendorong pembangunan berkelanjutan dalam mengatasi kemiskinan tanpa bergantung pada pendanaan pemerintah pusat.

Daerah Istimemewa Yogyakarta (Selanjutnya Yogyakarta) akan menjadi fokus penelitian. Latar belakang mengangkat Yogyakarta sebagai fokus penelitian karena pertama Yogyakarta adalah salah satu daerah di Indonesia yang berkomitmen mendukung pencapaian pembangunan berkelanjutan. Komitmen tersebut terlihat dalam keberhasilan Yogyakarta dalam mencapai 14 dari 17 indikator pembangunan berkelanjutan, bahkan Yogyakarta merupakan salah satu dari tiga provinsi yang siap melaksanakan pembangunan berkelanjutan. Hal tersebut disampaikan oleh Gubernur Yogyakarta Sri Sultan Hamengku Buwono X dalam dalam kunjungan kerja Badan Kerja Sama Antar Parlemen (BKSAP) DPR RI pada 23 Agustus 2019 (jogjaprov.go.id, 2019). Kedua, meskipun mampu melaksanakan sebagian besar indikator pembangunan berkelanjutan, akan tetapi masih terdapat satu indikator yang masih terkendala yaitu kemiskinan. Salah satu progam SDGs yang saat ini masih menjadi perhatian untuk diselesaikan oleh pemerintah daerah Yogyakarta adalah terkait dengan kemiskinan. Kendati demikian angka kemiskinan di Yogyakarta merupakan anomali yang tidak ditemukan di daerah lain. Sri Sultan Hamengkubuwono $X$ mengatakan bahwa kemiskinan di Yogyakarta tidak bisa disamakan dengan daerah lain karena seharusnya apabila angka kemiskinan tinggi, angka pendidikan dan kebahagiaan menjadi rendah. Namun kemiskinan Yogyakarta justru berkebalikan. Meskipun kemiskinan tinggi dan UMR terendah di Indonesia namun indeks kebahagiaan, harapan hidup serta pendidikan tinggi (bappeda.jogjaprov.go.id). Ketiga, Yogyakarta merupakan salah satu provinsi yang intensif dalam menjalin kerja sama internasional. Kerja sama internasional yang dilakukan oleh Yogyakarta bertujuan untuk meningkatkan kesejahteraan masyarakat daerah dan percepatan pelayanan publik. Dengan mengangkat kasus kerja sama internasional YogyakartaGyeongsangbukdo, artikel ini akan melihat upaya pemerintah daerah dalam mendukung agenda global pembangunan berkelanjutan dalam mengatasi kemiskinan melalui kerja sama internasional. 


\section{METODE PENELITIAN}

Penelitian ini bersifat deskriptif kualitatif yang bertujuan untuk menggambarkan strategi pemerintah dalam mengatasi kemiskinan melalui kerja sama internasional daerah. Melalui kerja sama internasional, diharapkan dapat melihat secara detil program-program yang dilakukan kedua daerah untuk mendukung pembangunan berkelanjutan. Sumber data primer diperoleh dari wawancara dengan nara sumber yaitu Kepala Subdivisi Kerja sama Luar Negeri BKPM (Badan Kerja sama dan Penanaman Modal) DIY, Kepala Subdivisi Penguatan Potensi Masyarakat BPPM (Badan Pemberdayaan Perempuan dan Masyarakat) DIY, Ketua Yayasan Global Saemaul Indonesia (YGSI) serta masyarakat desa Ponjong Gunung Kidul. Wawancara dilakukan dengan metode snowball interview yang bersifat mengalir dari hasil diskusi dengan narasumber. Dengan demikian diharapkan dapat diperoleh informasi lengkap mengenai kerja sama internasional daerah Yogyakarta-Gyeongsangbukdo. Sumber data sekunder diperoleh dari jurnal, dokumen, laporan penelitian serta artikel e-book yang akan dipergunakan untuk melengkapi data primer.

\section{PEMBAHASAN}

\section{Kemiskinan dan Tujuan Pembangunan Berkelanjutan}

Kemiskinan merupakan masalah kemanusiaan. Kemiskinan memberikan pengaruh bagi setiap orang untuk memiliki tanggung jawab moral peduli terhadap kehidupan orang lain yang terjebak dalam kemiskinan. Konvensi EKOSOB menegaskan bahwa kemiskinan merupakan salah satu wujud dari pelanggaran Hak-Hak Asasi Manusia. Di dalam sebuah keluarga miskin maka ada anggota keluarga seperti istri dan anak yang tidak mendapatkan makanan yang bergizi, pendidikan yang memadai, standar hidup yang rendah serta rentan terkena penyakit. Oleh sebab itulah pembiaran terhadap kemiskinan merupakan bentuk pelanggaran hak asasi manusia. Dengan demikian negara memiliki tanggung jawab moral untuk membebaskan masyarakatnya dari perangkap kemiskinan dengan cara menghormati, melindungi, dan memenuhi hak masyarakat atas kebutuhan dasar.

Pengentasan kemiskinan adalah prioritas utama pembangunan berkelanjutan. Pada akhir MDGs tahun 2015 kemiskinan dapat ditekan sampai 50 persen. Hal ini sesuai dengan target awal MDGs tahun 2000-2015 yaitu mengurangi separuh dari tiap-tiap masalah pembangunan yang tertuang dalam tujuan dan sasaran pembangunan berkelanjutan (Panuluh \& Fitri, 2016). Selanjutnya SDGs 2015-2030 bertujuan untuk mengakomodasi masalah-masalah pembangunan secara lebih komprehensif baik kualitatif (dengan mengakomodir isu pembangunan yang tidak ada dalam MDGs) maupun kuantitatif. Dengan demikian, upaya pengentasan kemiskinan masih tetap berlanjut dan menjadi prioritas pada SDGs tahun 2015 sampai tahun 2030 dengan menargetkan penyelesaian secara tuntas masalah kemiskinan. Untuk mengoptimalkan pencapaian SDGs maka semua negara baik negara maju, negara berkembang, dan negara kurang berkembang memiliki peran yang seimbang. Mereka harus berpartisipasi penuh terhadap pembangunan sesuai dengan peran dan tanggung jawab masing-masing. 
Daerah memiliki peran besar dalam mendukung upaya pencapaian SGDs dalam hal pengentasan kemiskinan. Fakta menunjukkan bahwa para kepala daerah sangat membantu dalam mengatasi masalahmasalah besar dunia seperti perubahan iklim, pencegahan terorisme, pengelolaan tata niaga perdagangan obat termasuk juga pengentasan kemiskinan. Hal ini dilatarbelakangi karena pemerintah daerah, kota dan kabupaten (a) memiliki posisi lebih dekat dengan warganya; (b) memiliki wewenang dalam kebijakan dan pengelolaan dana di daerah; (c) memiliki beragam cara untuk melakukan berbagai inovasi; serta (d) berperan penting dalam menyediakan layanan publik serta beragam kebijakan maupun program pemerintah (Barber, 2013). Hal ini bermakna pentingnya peran pemerintah kota dan daerah dalam mendukung tujuan pembangunan berkelanjutan. Keberadaan pemerintah daerah yang berhubungan langsung dengan masyarakat di tingkat lokal diharapkan dapat menggerakkan masyarakat untuk merubah nasib ke arah kehidupan sosial yang lebih baik.

Menyadari pentingnya partisipasi pemerintah daerah dalam pembangunan berkelanjutan, organisasi internasional yang mewakili kepentingan pemerintah daerah diseluruh dunia berpartisipasi dalam pertemuan tingkat tinggi dalam the World Summit on Sustainable Development di Johannesburg tahun 2002. Pada pertemuan tersebut pesan dari pemerintah daerah sangat jelas yaitu : Nation states cannot, on their own, centrally manage and control the complex, fast moving, cities and towns of today and tomorrow - only strong decentralized lokal governments, in touch with and involving their citizens, and working in partnership with national governments, are in a position to do so (Jain, 2017). Keberhasilan pemerintah daerah dalam mengatasi kemiskinan melalui dalam pembangunan daerah akan berperan besar dalam mendukung tujuan pembangunan nasional.

Selanjutnya keterlibatan pemerintah daerah dalam mendukung SGDs dipertegas dalam pembentukan gugus tugas yang terdiri dari berbagai organisasi dan asosiasi kota serta kepala daerah, diantaranya International Council for Local Environmental Initiatives (ICLEI), The Network of Regional Governments for Sustainable Development (nrg4SD), and United Cities and Local Governments (UCLG). Dalam forum tersebut kepala daerah dari seluruh dunia berkomitmen dalam merencanakan, membuat keputusan dan mengimplementasikan global development agenda. Selanjutnya melalui the achievement of the global agendas from the bottom-up, pemerintah daerah dari berbagai negara menghasilkan New Urban Agenda. "New Urban Agenda" (NUA) adalah hasil kesepakatan pada Habitat III Cities Conference di Quito, Ecuador pada bulan Oktober 2016, yang merupakan penegasan komitmen global dalam pembangunan daerah dan perkotaan yang berkelanjutan. Pertemuan tersebut menunjukkan bahwa bahwa cara untuk mencapai pencapaian SDGs hanya akan dimungkinkan melalui potensi percepatan New Urban Agenda. Kepemimpinan lokal dan penyediaan layanan lokal berperan penting mendorong pembangunan dengan cara yang berakar pada realitas budaya, sosial, lingkungan dan ekonomi di setiap wilayah. Itulah sebabnya fungsi pemerintah lokal dan regional dalam pengembangan, implementasi, dan pelaporan kebijakan internasional adalah untuk melokalkan tujuan pembangunan global. Terkait dengan upaya 
mengatasi kemiskinan, salah satu asosiasi kota serta kepala daerah UCLG mendeklarasikan bahwa pada tahun 2030, pemerintah daerah mampu mengentaskan kemiskinan ekstrim untuk seluruh masyarakat di dunia, yaitu masyarakat yang hidup di bawah $\$ 1.25$ per hari (UCLG, n.y). Oleh sebab itulah kemitraan antar pemerintah daerah dalam dan luar negeri dapat berperan besar dalam menunjang target-target tersebut.

\section{Kerja sama Internasional daerah dalam Mendukung Pembangunan Berkelanjutan Mengatasi Kemiskinan}

Sejak desentralisasi diberlakukan, pemerintah daerah memiliki keleluasaan dalam mencari jalan untuk meningkatkan sumber pendapatan. Hal ini sejalan dengan tanggung jawab pemerintah daerah untuk lebih tanggap terhadap masalah dan kebutuhan daerah (Noor, 2012). Pemerintah daerah diharapkan lebih memahami kebutuhan dan kapabilitas masyarakatnya dibandingkan dengan pemerintah pusat (Miranti et al., 2013). Dengan demikian desentralisasi menjadi celah bagi pemerintah daerah untuk mempertimbangkan berbagai upaya pemenuhan kebutuhan warga. Gerak cepat pemerintah daerah dalam memenuhi kebutuhan domestik daerah akan membantu mengatasi kendala pembangunan daerah.

Sejalan dengan berlakunya otonomi daerah, peran dan kewenangan pemerintah daerah bertambah luas termasuk salah satunya adalah melakukan hubungan internasional. UU no 22 tahun 1999 menyebutkan bahwa pemerintah daerah juga memiliki kesempatan melaksanakan hubungan luar negeri. Lebih lanjut didalam UU no 23 tahun 2014 ditegaskan tentang pembagian kekuasaan pemerintah pusat dengan pemerintah daerah yang menyebutkan bahwa diplomasi yang bisa dilaksanakan pemerintah daerah antara lain bidang ekonomi, sosial, budaya pendidikan dan sebagainya. Sebagai pedoman bagi daerah dalam melaksanakan hubungan internasional maka Kementerian Luar Negeri menerbitkan Peraturan Menlu RI No 3 Tahun 2019 mengenai Hubungan Luar Negeri oleh Pemerintah Daerah dan Peraturan Menteri Dalam Negeri No 3 tahun 2008 tentang Pedoman Pelaksanaan Kerja sama Pemerintah Daerah dengan Pihak Luar Negeri. Serangkaian regulasi tersebut semakin membuka jalan bagi daerah untuk meningkatkan jejaring kerja sama dengan berbagai mitra luar negeri. Kendati demikian kerja sama yang dijalin tetap harus didasarkan pada koridor yang telah ditetapkan pemerintah pusat yaitu kerja sama dapat dilakukan antar daerah yang memiliki hubungan diplomatik serta berfokus pada kerja sama nonpolitik.

Meningkatnya kerja sama internasional daerah di Indonesia semakin terbuka sejalan dengan kesepakatan yang tertuang dalam MDGs melalui serangkaian komitmen semua negara untuk menyukseskan MDGs. Dalam piagam MDGs tahun 2000 tersebut disepakati bahwa negara maju didorong untuk mendukung program MDGs dengan menyediakan dana bantuan bagi negara-negara berkembang. Selanjutnya di dalam kesepakatan SDGs tahun 2015 disetujui bahwa tiap-tiap negara harus bekerja sama untuk menemukan sumber pembiayaan dan perubahan kebijakan yang diperlukan. Kesepakatan ini menjadi dasar bagi negara-negara maju untuk memberikan berbagai macam hibah dan berbagai pembiayaan dari luar negeri untuk keperluan meningkatkan aktifitas perekonomian serta mendorong pembangunan. Bagi 
pemerintah daerah di Indonesia kesepakatan dalam MDGs menjadi jalan bagi mereka untuk memperluas jejaring kerja sama dan mendapatkan bantuan pendanaan dalam mendukung pembangunan daerah.

Bantuan pembiayaan pembangunan dari negara-negara donor semakin meningkat. Beragam bantuan berupa hibah dari luar negeri disampaikan dalam rangka membiayai proyek-proyek pembangunan. Berbagai bentuk pembiayaan pembangunan disediakan oleh negara donor seperti mempromosikan pemerintahan yang demokratis; memberikan insentif pada kebijakan negara mitra yang pro-kaum miskin, mengentaskan kemiskinan melalui pertumbuhan; memfasilitasi perdagangan; meningkatkan kualitas hidup masyarakat, mendorong perubahan politik yang konduksif, mendorong kemandirian kaum miskin atas dasar kebutuhan, mediasi ketidakseimbangan struktural di kedua negara penerima; pengembangan, manajemen dan transfer pengetahuan, teknologi, serta penyediaan layanan publik (Sumner \& Mallett, 2012). Dalam menjalin komunikasi dengan mitra, beberapa negara donor lebih jauh memutuskan untuk menyediakan bantuan kepada daerah secara langsung tanpa melalui perantara pemerintah pusat (Ariadi, 2000). Hibah tersebut diberikan untuk berbagai aktifitas yang disiapkan oleh daerah baik yang dikelola oleh pemerintah daerah maupun LSM-LSM lokal. Beberapa sektor-sektor prioritas dipilih sesuai dengan keahlian dan kebutuhan masing-masing. Di sinilah mereka secara terprogram dan terencana melakukan pendekatan dengan pemerintah daerah dalam mendukung pengembangan kerja sama pembangunan khususnya kerja sama teknik dalam bentuk hibah.

Sejalan dengan terbukanya kesempatan untuk kerja sama luar negeri, berbagai daerah di Indonesia secara intensif meningkatkan interaksi internasionalnya. Beberapa menunjukkan keberhasilan misalnya kerja sama internasional daerah antara Kota Surabaya dengan Seattle (AS), Kota Padang dengan Rhudeshine (Jerman), Propinsi Jawa Barat dengan Kiyonggi (Jepang) Kota Bandung dengan Forth Worth (Amerika Serikat), Kota Banda Aceh dengan Samarkand (Uzbekhistan), Propinsi Sumatera Utara dengan Vermont (AS), Propinsi Jawa Timur dengan Kyongsung-nan-Do (Korea Selatan), Propinsi Irian Jaya dengan Yamagata (Jepang). Mereka mendapatkan banyak manfaat dari kerja sama internasional tersebut.

Mendukung pembangunan daerah berkelanjutan melalui pengentasan kemiskinan merupakan salah satu skema hibah pembangunan dari negara donor (Sumner \& Mallett, 2012). Kondisi kemiskinan dan ketidaksetaraan sosial negara-negara penerima terutama negara-negara yang memiliki keterbatasan sumber daya atau sumber daya yang cukup tetapi sarat dengan konflik internal menjadi pertimbangan negara-negara pendonor dalam memberikan hibah. Meskipun demikian, pemberian hibah dari negara donor tetap saja menjadi dilema bagi negara-negara sedang berkembang. Meskipun idealnya hibah dari negara donor menjadi salah satu cara meningkatkan kemandirian masyarakat, mendorong pembangunan daerah, serta mengurangi kemiskinan dan kesenjangan, akan tetapi tetap saja dibutuhkan pemahaman yang lebih luas dalam memaknai dibalik hibah tersebut. Bantuan tersebut digerakkan oleh tujuan politik, menambah kekuatan dan pengaruh di negara penerima, memperluas pengaruh budaya, sebagai bentuk apresiasi kepada negara dengan karena sudah berperilaku sesuai dengan persyaratan negara donor, dan 
sebagai usaha untuk mendapatkan akses di negara penerima (Lancaster, 1390). Dengan demikian daerah penerima bantuan harus melakukan penyesuaian-penyesuaian atas persyaratan-persyaratan yang diberikan oleh negara donor.

\section{Kerjasama Internasional Yogyakarta dalam Mendukung Pembangunan Berkelanjutan}

Yogyakarta merupakan salah satu daerah yang berkomitmen untuk mencapai pembangunan berkelanjutan. Hal tersebut tercermin dari pidato pengukuhan jabatan Gubernur Yogyakarta periode 20172022 dalam Sidang Paripurna istimewa DPRD tahun 2017 lalu. Dalam pidatonya Gubernur menyampaikan visi berjudul "Menyongsong Abad Samudera Hindia untuk Kemuliaan Martabat Manusia Jogja" serta misi yang bernama "Lima Kemuliaan" atau "Pancamulia". Dalam penyampaian misinya, Gubernur memaparkan dua misi pertama yang akan dicapai adalah meningkatkan kesejahteraan masyarakat serta pemerataan ekonomi. Pidato tersebut menunjukkan arah dan tujuan daerah dalam mewujudkan pembangunan berkelanjutan melalui peningkatan aktifitas ekonomi masyarakat.

Yogyakarta memiliki empat kabupaten dan satu kota, diantaranya adalah Kabupaten Kulon Progo, Gunung Kidul, Bantul, Sleman dan Kota Yogyakarta. Yogyakarta adalah salah satu daerah di pulau Jawa dengan tingkat kemiskinannya tertingi diantara kota-kota lain di pulau Jawa. Apabila Dibandingkan dengan provinsi lain yang terletak di pulau Jawa maka Yogyakarta belum mengalami penurunan prosentase kemiskinan yang signifikan. Data Bappenas tahun 2016 menunjukkan bahwa diantara provinsi lain di pulau Jawa, maka angka kemiskinan di Yogyakarta adalah yang tertinggi yaitu mencapai 16,6\%. Adapun provinsi yang tingkat kemiskinannya paling rendah di pulau Jawa adalah Jawa Barat dengan 11,8\% diikuti dengan Jawa Tengah adalah $14,9 \%$ dan Jawa Timur mencapai 16\%. Angka tersebut jauh diatas target penurunan kemiskinan yang ditetapkan oleh Pemerintah nasional tahun 2016 yaitu 10\% (Deputi Menteri PPN/Kepala Bappenas Bidang Kependudukan dan Ketenagakerjaan, 2017). Dari jumlah tersebut dua kabupaten Yogyakarta dengan kemiskinan tertinggi adalah Bantul berjumlah 131,15 jiwa dan Gunung Kidul berjumlah 123,08 jiwa. Pemerintah Yogyakarta sendiri menargetkan akan menurunkan jumlah kemiskinan sebesar 12\% di tahun 2020 (http://bappeda.jogjaprov.go.id/dataku/infografik/kemiskinan). Tingginya angka kemiskinan di Bantul dan Gunung Kidul menjadi perhatian utama pemerintah Yogyakarta dalam mengatasi problem kemiskinan.

Salah satu cara pemerintah Yogyakarta untuk mengatasi kemiskinan adalah melalui kerja sama internasional. Kerja sama internasional Yogyakarta bertujuan untuk meningkatkan efisiensi dan efektifitas pelayanan publik (BKPM DIY, 2017). Melalui kerja sama internasional ini diharapkan dapat mendorong aktifitas perekonomian daerah. Salah satu kerja sama yang dilakukan Yogyakarta adalah kerja sama internasional Yogyakarta-Gyeongsangbukdo. Kerja sama dengan provinsi Gyeongsangbukdo ditujukan untuk memberikan wadah bagi masyarakat untuk lebih mandiri dalam aktifitas perekonomian dan mendorong pembangunan daerah. 
Ketertarikan Yogyakarta bekerja sama dengan Gyeongsangbukdo berawal dari keberhasilan Korea Selatan dalam menerapkan program Saemaul Undong. Program ini berbasis pada upaya mengatasi kemiskinan melalui pengembangan daerah pedesaan (Anwar, 2017). Berkat program ini Korea Selatan mengalami kemajuan, melepaskan diri dari kemiskinan melalui penurunan tingkat kemiskinana nasional sebesar 17,1\% bahkan menjadi salah satu negara berpengaruh di dunia (Douglass, 2013).

Menggarisbawahi keberhasilan Korea Selatan, maka Yogyakarta tertarik untuk juga mengembangkan program ini. Hal itu terlihat dari kesiapan Yogyakarta dalam penandatanganan kerja sama kedua daerah. Kerja sama Indonesia-Gyeongsangbukdo berlangsung dalam dua periode yaitu tahun 2008-2011 dan 20152020 (Wawancara Setiono, 17 Desember 2018). Mengacu pada tingginya angka kemiskinan di kabupaten Gunung Kidul dan Bantul, maka pada periode 2015-2020 difokuskan pada daerah tersebut. Salah satu desa percontohan yang dikembangkan dalam kerja sama internasional daerah adalah desa Ponjong Kecamatan Ponjong Gunung Kidul.

Desa Ponjong merupakan ibu kota Kecamatan Ponjong, Kabupaten Gunungkidul. Desa Ponjong terletak 15 km dari pusat kota Wonosari, dan 52 Km dari pusat kota Yogyakarta. Luas wilayah Desa Ponjong adalah $628.042 \mathrm{Ha}$. $60 \%$ dari luas wilayah tersebut merupakan kawasan lindung yang terdiri dari tanah pertanian, lahan basah, lahan kering, dan kawasan Sumber Mata Air Ponjong. Sementara 40\% wilayahnya merupakan area budi daya atau pengembangan yang difungsikan untuk pemukiman, area perikanan dan ternak, area komersil, area failitas umum, dan area industri rumah tangga. Di desa Ponjong terdapat 1.633 kepala keluarga dengan jumlah penduduk sebanyak 5.150 jiwa yang terbagi ke dalam 11 wilayah padukuhan. Mayoritas pekerjaan warga Desa Ponjong adalah petani atau pekebun. Desa Ponjong memang terkenal dengan sumber air-nya Sumber Mata Air Ponjong yang terletak bersebelahan dengan Kantor Kepala Desa Ponjong. Sumber air ini telah dikembangkan oleh Bumdes Hanyukupi Desa Ponjong menjadi sebuah wisata air bernama Waterbyur dengan pendapatan yang cukup tinggi setiap tahunnya. Selain itu, sumber air yang melimpah membuat pertanian sawah basah di Desa Ponjong menghasilkan panen 3 kali selama satu tahun (Profil Potensi Desa Ponjong, https://www.ponjong.desa.id/first/artikel/59) akses tanggal 5 April 2020).

Selain kegiatan pertanian dan perkebunan, warga desa Ponjong juga kebanyakan beternak seperti halnya penduduk Gunungkidul pada umumnya. Adanya kegiatan peternakan dan pertanian ini merupakan salah satu potensi utama pengembangan usaha desa. Pertanian dan peternakan bisa dikembangkan menjadi usaha agribisnis yang terintegrasi untuk menunjang perekonomian warga.

\section{Kerjasama Internasional Yogyakarta-Gyeongsangbukdo}

Kerja sama Yogyakarta - Gyeongsangbukdo di desa Ponjong memfokuskan pada upaya mendorong agar aktifitas perekonomian desa dapat berkembang melalui kemandirian masyarakat sesuai 
dengan kebutuhan mereka. Dengan demikian diharapkan jika kerja sama telah selesai, program pengembangan desa dapat terus dilanjutkan oleh masyarakat. Kerja sama tersebut melibatkan masyarakat secara menyeluruh mulai dari perencanaan program, implementasi program dan juga evaluasi. Mereka menjadi bagian yang berperan penting yang menentukan keberhasilan kerja sama.

Pada 31 Agustus 2015, Pemerintah Provinsi Gyeongsangbuk-do Korea Selatan dan Pemerintah Daerah Daerah Istimewa Yogyakarta menandatangani penegasan kembali memorandum saling pengertian kerja sama sister province. Melalui penandatanganan perjanjian tersebut, kedua pemerintah daerah sepakat untuk menghidupkan kembali program Saemaul Undong di Daerah Istimewa Yogyakarta yang pernah dilaksanakan di tahun 2008 (Wawancara Anwari dari BPPM DIY, Januari 29, 2019). Pemerintah Yogyakarta diwakili oleh Badan Pemberdayaan Perempuan dan Masyarakat (BPPM) serta pihak pemerintah Provinsi Gyeongsangbuk-do diwakili oleh Saemaul Globalization Foundation menandatangani pengaturan teknis kerja sama Pembangunan Desa Percontohan Saemaul.

Keterlibatan masyarakat dalam kerja sama internasional sangat besar. Mereka meliputi pengurus desa, unit usaha desa (Bumdes), serta para peternak dan petani. Lembaga masyarakat yang lain juga ikut dilibatkan yaitu YGSI (Yayasan global Saemaul Indonesia) yang bertindak mewakili pemerintah Gyeongsangbukdo, lembaga swadaya masyarakat lokal yaitu yayasan Penabulu serta universitas. YGSI dan pemerintah daerah berperan dalam mengawal dan memonitor program agar terus terlaksana dan berkesinambungan. Sementara itu Yayasan Penabulu dan universitas akan memberikan pelatihan dan penelitian. Fasilitator dari Yayasan Penabulu bertugas mengarahkan ide-ide dari relawan Korea dan warga desa agar menjadi suatu kesepakatan Bersama (Laporan Berkala Pembentukan Desa Percontohan Saemaul bulan Januari-Maret, 2017). Komunikasi antara pihak Korea Selatan dan masyarakat dijembatani oleh penerjemah dari Korea dan Indonesia. Kolaborasi diantara unsur-unsur tersebut diatas menjadi motor penggerak pelaksanaan program Pembangunan Desa Percontohan.

Kerja sama Yogyakarta-Gyeongsangbukdo pada periode kedua dilaksanakan dalam lima tahun berjalan yaitu tahun 2015 sampai 2020. Menurut Soleh Anwari dari BPPM DIY, ada beberapa target kerja sama yang akan dicapai setiap tahun. Tahun pertama berfokus pada penggalian potensi desa, pelatihan peningkatan kapasitas. Tahun kedua melaksanakan usaha desa sesuai dengan usulan dari desa, yaitu pengadaan kandang sapi komunal. Tahun ketiga mengarah pada optimalisasi kegiatan usaha desa serta tahun keempat dan kelima berkonsentrasi pada peningkatan keuntungan usaha desa (Wawancara Anwari, 29 Januari 2019). Dalam pencapaian pembangunan berkelanjutan melalui pengentasan kemiskinan maka kerja sama internasional difokuskan beberapa upaya yaitu : transfer ilmu pengetahuan, pemberdayaan masyarakat, dan penyediaan fasilitas publik. Strategi tersebut saling bersinergi untuk mendorong masyarakat agar mampu memaksimalkan potensi sumber daya yang tersedia dan menghidupkan aktifitas perekonomian warga. 


\section{Transfer Ilmu Pengetahuan}

Salah satu pengalaman yang diperoleh dari kerja sama internasional adalah mendapatkan makna pembangunan negara luar untuk menginspirasi pembangunan dalam negeri. Pemahaman mengenai keberhasilan negara luar dalam mengelola potensi sumber daya yang tersedia sehingga mengatasi berbagai persoalan pembangunan dapat menjadi role mode/ bagi negara lain (Setiawati, 2015). Hal yang sama juga terjadi dalam kerja sama internasional Yogyakarta-Gyeongsangbukdo. Keberhasilan Korea Selatan dalam mengelola pembangunan sehingga bermanfaat secara signifikan bagi masyarakatnya menjadi pertimbangan untuk mendapatkan transfer ilmu pengetahuan tentang nilai-nilai tersebut dalam menginspirasi pembangunan Indonesia.

Sejak globalisasi dikendalikan oleh kekuatan neoliberal melalui World Trade Organization (WTO), negara-negara maju berhasil memaksa negara-negara dunia untuk menerapkan kebijakan perdagangan bebas atau mereka akan terisolasi di arena internasional yang didominasi negara-negara kapitalis. Hal ini menyebabkan negara-negara dunia ketiga mengorbankan kepentingan nasional untuk mengikuti tren globalisasi. Akibatnya kemiskinan dan kesenjangan di negara-negara dunia ketiga semakin meningkat. Pemerintah fokus pada modernisasi dan industrialisasi sehingga menyebabkan daerah-daerah pinggiran dan pedesaan mengalami kemunduran dan kemiskinan.

Program Saemaul Undong muncul sebagai upaya mengatasi kemiskinan di Korea Selatan. Program tersebut mendunia dan mulai banyak diterapkan diberbagai negara. Sistem ini berbasis pengembangan kantong-kantong kemiskinan di terutama di daerah pedesaan melalui pemberdayaan masyarakat. Masyarakat desa yang semula menggantungkan diri pada bantuan pemerintah menjadi maju dan berkembang dengan mengoptimalkan sumber daya yang tersedia disekitar.

Program Saemaul Undong berawal dari ketidakadilan yang dirasakan oleh masyarakat Korea Selatan di era 70-an. Berawal pada masa pemerintahan presiden Park Chung Hee melalui Rencana Lima Tahun pertama dan kedua (1962-1971) yang fokus pada meningkatkan pertumbuhan ekonomi melalui industrialisasi. Akan tetapi program tersebut berdampak pada melebarnya jurang antara masyarakat kaya dengan dan masyarakat miskin terutama di wilayah pedesaan sehingga memperlambat proses modernisasi. Keinginan Park Chung Hee untuk segera mengatasi kesenjangan dan kemiskinan dilakukan dengan cara memprakarsai pembangunan pedesaan yang dikenal dengan Saemaul Undong.

Program Saemaul Undong mengatasi kemiskinan dan kesenjangan melalui pembangunan dan modernisasi di pedesaan. Target utama program ini meningkatkan produktifitas dan meningkatkan kesejahteraan masyarakat desa. Masyarakat setempat menjadi pusat dalam pengembangan dengan tujuan agar lebih mandiri berdasarkan kebutuhannya, Dari kegiatan ini diharapkan masyarakat mampu membangun desanya sesuai dengan kapasitas dan sumber daya masing-masing wilayah. Untuk mendukung program ini nilai-nilai tradisional masyarakat Korea selatan dikembangkan yaitu rajin (diligence), mandiri (self-he/p) dan gotong royong (cooperation) (Reed, 2010). Nilai-nilai tersebut dipegang 
kuat masyarakat dan menjadi sumber gerakan revolusi mental dengan tujuan meningkatkan kesejahteraan, memperbaiki lingkungan fisik dan sosial masyarakat.

Gerakan revolusi mental Korea Selatan mengajak masyarakatnya untuk mengembangkan kemampuan diri sendiri melalui kerja sama yang baik dengan lingkungan sekitarnya. Gerakan ini berhasil membangkitkan keinginan masyarakat untuk membangun desa sehingga mendukung kebijakan pembangunan yang dilaksanakan pemerintah. Program ini berhasil membawa Korea Selatan dari negara miskin menjadi negara berpengaruh di dunia. Pada era 1970-an, Korea Selatan melalui sistem ini berhasil menurunkan angka kemiskinan nasional sebesar $17,1 \%$. Pendapatan perkapita penduduk meningkat tajam dari US\$1.025 pada tahun 1971 menjadi US\$2.961 pada tahun 1977. Sejak saat itu, sistem ini dikaji secara intensif, diformulasi secara terpadu, dan telah diadopsi oleh 70 negara di kawasan Asia, Afrika, dan Amerika Latin (Douglass, 2013).

Dibawah pemerintahan Park Chung Hee rencana pembangunan lima tahun pada tahap ketiga (1972-1976) dilaksanakan melalui gerakan Saemaul Undong yang mencanangkan program ketercukupan kebutuhan pangan penduduk dari produksi sendiri serta pembangunan pedesaan melalui modernisasi desa seperti perbaikan jalan desa, listrik masuk desa, pengenalan bibit unggul, partisipasi perempuan dalam pembangunan desa dan pelatihan kepemimpinan (Douglas, 2013). Kepercayaan diri masyarakat Korea Selatan menjadi terbentuk dengan sangat baik. Dengan demikian program Saemaul Undong ini memberikan solusi mendasar bagi persoalan-persoalan ekonomi masyarakat pedesaan.

Sejalan dengan keberhasilan yang telah dicapai, program ini kemudian menyebar ke berbagai wilayah bahkan diadopsi oleh beberapa kawasan seperti Asia, Africa dan Amerika (Reed, 2010). Kendati demikian program Saemaul Undong tetap harus menyesuaikan kondisi setiap negara yang mungkin berbeda dari negara asal Saemaul Undong baik dari sisi kapasitas lembaga pemerintahan, kepemimpinan yang kuat, serta kebijakan nasional yang mendukung pengembangan desa.

Mengglobalnya program ini menarik perhatian pemerintah Indonesia untuk diterapkan. Ketertarikan Indonesia dalam mengimplementasikan program Saemaul Undong dilatarbelakangi oleh beberapa kemiripan. Pertama, Indonesia seperti halnya Korea Selatan pernah mengalami mengalami masa ketidakstabilan politik dan krisis militer. Pasca krisis masyarakat Indonesia meskipun sempat mengalami era swasembada beras tahun 1979 namun jumlah petani semakin berkurang. Hal tersebut berpengaruh besar dalam pengembangan pembangunan pedesaan sebagai tempat dengan kemiskinan yang tinggi. Kedua, Indonesia dan Korea Selatan memiliki kesamaan nilai dan kearifan lokal gotong royong melalui partisipasi masyarakat secara mandiri (ugm.ac.id, 2016) meskipun demikian di Indonesia nilai-nilai lokal tersebut semakin tergerus dengan arus modernisasi dan industrialisasi sehingga merubah gaya hidup masyarakat menjadi kurang peduli terhadap lingkungan sekitar. Ketiga, Indonesia dan Korea Selatan adalah dua negara yang mewarisi sektor pedesaan berorientasi ekspor yang berlebihan pada masa pemerintahan kolonial. Meskipun demikian, di Indonesia pembangunan pedesaan tampak belum tuntas seperti apa yang dilakukan 
di Korea Selatan (Setiawati, 2015). Cara pandang pembangunan ekonomi melalui eksploitasi wilayahwilayah tanpa mempertimbangkan aspek pemerataan dan memperhitungkan asas nilai tambah membuat nilai di Indonesia semakin tergerus (ugm.ac.id, 2014) bahkan semakin meningkatkan kesenjangan dan kemiskinan.

Persoalan kemiskinan di Indonesia berawal dari orientasi pembangunan Indonesia yang menekankan pada modernisasi dan industrialisasi sehingga pembangunan di pedesaan kurang menjadi fokus perhatian pemerintah. Akibatnya kemiskinan di daerah pedesaan semakin tinggi. Masyarakat lebih memilih untuk melakukan urbanisasi atau menjadi buruh pabrik dibandingkan membangun desa. Daerah pedesaan tidak bisa menjadi modal pembangunan karena sumber daya manusia yang rendah.

Belajar dari keberhasilan Korea Selatan melalui Saemaul Undong, memunculkan pemikiran untuk menghidupkan kembali gotong royong dan rajin serta kerja keras diantara sesama masyarakat dalam rangka mewujudkan rencana-rencana pembangunan. Dengan demikian diharapkan pembangunan pedesaan dapat membantu masyarakat desa lebih maju dan berkembang sekaligus melepaskan diri dari perangkap kemiskinan. Gerakan pembangunan yang digerakkan oleh masyarakat dengan menekankan pada semangat ketekunan, swadaya, dan kerja sama hingga menjadi masyarakat yang mandiri itulah yang ingin dikembangkan. Keinginan untuk bekerjasama tidak hanya bertujuan melestarikan tradisi saling membantu, melainkan juga membantu individu untuk memperbaiki kehidupannya dengan meningkatkan sikap partisipasi dan kompetisi. Dapat disimpulkan bahwa kerja sama internasional YogyakartaGyeongsangbukdo dapat menjadi transfer ilmu pengetahuan berupa nilai-nilai lokal Indonesia mengenai cara penguatan kapasitas masyarakat untuk lepas dari ancaman kemiskinan dan bergerak untuk meningkatkan kesejahteraan.

Melalui kerja sama internasional dengan Gyeongsangbukso Yogyakarta mendapatkan pelajaran berharga dari Korea Selatan mengenai upaya menyinergikan sumber daya yang ada di tingkat masyarakat agar bisa menjadi sarana penting mencapai kesejahteraan. Selain itu juga menumbuhkan kemandirian masyarakat sehingga dapat menciptakan penghargaan bagi diri sendiri serta pentingnya koordinasi serta serta komunikasi selama pelaksanaan program. Hal ini yang membuat program dapat berjalan dengan baik.

\section{Pemberdayaan Masyarakat}

Kerja sama internasional Yogyakarta-Gyeongsangbukdo menempatkan masyarakat sebagai mitra kerja sama. Pertimbangan pelibatan tersebut karena masyarakat yang lebih memahami potensi serta kondisi daerah dimana mereka tinggal (Bamberger, 1986). Dengan demikian diharapkan program kerja sama dapat berjalan secara optimal dan memberikan manfaat nyata. Kerja sama dilakukan dengan model botom-up yaitu melibatkan partisipasi masyarakat secara aktif disetiap tahapan kerja sama dimulai dari perencanaan, implementasi, memperoleh hasil serta monitoring (Cohen \& Uphoff, 1980). Pelibatan 
masyarakat secara aktif didasarkan pertimbangan untuk menjamin bahwa rintisan usaha yang dilakukan akan terus dikembangkan secara berkelanjutan.

Bentuk partisipasi masyarakat adalah melibatkan pengurus dan warga desa sebagai agen yang akan bertanggung jawab untuk melanjutkan usaha desa. Pemberdayaan masyarakat diawali tahun pertama masyarakat diberikan pelatihan dan diskusi dalam rangka menggali potensi desa. Pelatihan berkaitan dengan pengembangan peternakan dan pertanian serta pemberdayaan perempuan. Masyarakat diberikan penjelasan mengenai bagaimana merintis usaha, mencari pasar, memasarkan sampai dengan memperoleh hasil usaha. Pelatihan diberikan oleh YGSI dan Yayasan Penabulu. Selanjutnya mereka yang akan mendampingi dan memonitor program (Wawancara Anwari, 29 Januari 2019)

Usai memberikan pembekalan serta pelatihan maka pada tahun akhir 2016 desa Ponjong mempresentasikan rencana usaha yang akan dikembangkan di pada tahun 2017 di hadapan pemerintah Yogyakarta dan Gyeongsangbukdo. Desa Ponjong mengajukan proposal unit usaha pengembangkan program jangka panjang kearah pengembangan desa sebagai sentra pertanian organik. Untuk mencapai hal itu maka langkah bertahap dilakukan dengan diawali dari peternakan sapi komunal (Laporan berkala Pembentukan Desa Percontohan Saemaul bulan Desember 2015-Februari, 2016). Pertimbangannya adalah kebutuhan daging sapi di Yogyakarta sangat tinggi sehingga usaha peternakan sapi memiliki potensi berupa keuntungan yang besar. Selain itu, limbah sapi berwujud kotoran dapat diolah menjadi pupuk organik bernutrisi tinggi. Pupuk organik itu dapat dimanfaatkan para petani untuk memupuk tanaman padi. Para ibu juga bisa diajak untuk mulai menanam sayuran organik di pekarangan rumahnya. Selain pengurus desa dan masyarakat, kerja sama ini juga melibatkan unit usaha (Bumdes) yang akan bertugas mengelola usaha.

Pada tahun kedua, program pengembangan peternakan sapi dengan sistem komunal mulai dilakukan. Pada awal budidaya ternak, tiga puluh tiga ekor sapi dibeli dalam dua tahapan yaitu bulan tahap pertama November 2017 dan tahap kedua Desember 2017. Sapi-sapi tersebut akan dipelihara oleh penggaduh yang akan merawat dan mengembang biakkan sapi dengan sistem bagi hasil. Pada awalnya YGSI menginginkan pembagian keuntungan antara penggaduh dan pengelola sebesar 50:50. Dalam perkembangannya setelah ada perdebatan diantara para pihak akhirnya disepakati bahwa pembagian keuntungan itu minimal 60:40 atau bahkan sampai 70:30. Hal ini didasarkan pertimbangan bahwa jika perbandingan keuntungan sejumlah 50:50 maka tidak akan ada penggaduh yang mau mengikuti program ini karena umumnya pembagian keuntungan 60:40 (YGSI, 2019).

Agar masyarakat memiliki tanggung jawab dalam mengelola program maka Pemerintah Desa Ponjong mengatur anggaran desa untuk penyertaan modal usaha bagi Bumdes. Modal usaha tersebut akan digunakan Bumdes untuk membeli bibit sapi yang akan digemukkan. Dari penyertaan modal ini Bumdes mampu membeli enam ekor bibit sapi yang akan digemukkan. Semua sapi penggemukan yang merupakan modal awal dari Gyeongsangbukdo dan yang dimiliki oleh Bumdes dipelihara dengan sistem gaduh. 
Pengembangan ternak sapi oleh penggaduh dilakukan pada tahun ketiga. Mereka didampingi oleh ahli sapi dari Korea Selatan yang bertugas untuk memberikan masukan dan memonitor perkembangan sapi (Laporan Berkala Pembentukan Desa Percontohan Saemaul bulan Maret-Juni, 2018). Petugas memberikan beberapa pelatihan kepada penggaduh mengenai perawatan sapi, mengecek kondisi kesehatan sapi, dan melakukan perbaikan beberapa bagian kandang yang kurang baik. Demikian pula YGSI dan pemerintah daerah memonitor setiap perkembangan perubahan pada sapi agar program penggemukkan dan pengembangbiakkan dapat berjalan dengan baik.

Pada tahun keempat program tersebut mulai menunjukkan hasil. Beberapa ekor anak sapi lahir. Meskipun demikian ada pula sapi yang mati karena sakit (YGSI, 2019). Pendampingan ditingkatkan tidak hanya mendatangkan ahli sapi pihak Korea Selatan saja tetapi juga melibatkan ahli sapi dari dari dalam negeri. Tujuannya adalah mengoptimalkan upaya untuk pengelolaan ternak karena system ternak di Korea dan Indonesia memiliki sedikit perbedaan. Mereka mendampingi dalam hal mengelola peternakan dengan didukung survei mengenai sistem pengelolaan, kualitas pakan, peluang penjualan, dan lain sebagainya.

Survei dilakukan untuk memperoleh dasar-dasar pengelolaan ternak sapi yang ideal. Menurut Ketua YGSI Nurmaya Pradipta, survei tersebut dikerjakan terus-menerus di berbagai pabrik-pabrik pakan, peternakan, pasar-pasar hewan, dan tempat lain yang terkait serta dilakukan di sela-sela kegiatan pendampingan program di desa percontohan (Wawancara Pradipta, 29 Januari 20019). Hasil survei akan menjadi pertimbangan permulaan proses usaha perbaikan manajemen karena manajemen usaha mulai dari perencanaan, analisis usaha, pemasaran, dan suplai chain yang merupakan faktor penentu seperti lingkaran rantai yang tidak bisa terputus. Keterlibatan semua pihak menjadi penting karena akan menentukan masa depan rencana pengembangan peternakan sapi komunal.

\section{Penyediaaan fasilitas publik}

Salah satu program kerja sama yang juga dirasakan manfaatnya oleh Yogyakarta adalah menyediakan fasilitas publik. Menyediakan fasilitas publik penting dalam mengatasi kemiskinan karena memungkinkan kelompok miskin mendapatkan fasilitas yang lebih baik, dan meningkatkan partisipasi mereka dalam menyelesaikan masalah-masalah daerah. Penyediaan fasilitas publik juga dapat mengurangi arus urbanisasi dan mengembangkan sumber daya manusia.

Kerja sama internasional daerah merupakan sarana bagi daerah untuk mendukung upaya penyediaan fasilitas publik. Dalam konteks kerja sama Yogyakarta-Gyeongsangbukdo, dukungan Gyeongsangbukdo dalam menyediakan fasilitas publik dilakukan sebagai bagian dari program pemberdayaan masyarakat melalui melalui pembuatan kandang sapi komunal dan pembangunan gedung untuk tempat pertemuan.

Pembangunan kandang sapi komunal adalah salah satu upaya untuk mendukung image Gunung Kidul sebagai gudang ternak dan gudang pertanian. Sebenarnya warga Desa Ponjong sudah terbiasa 
dengan peternakan sapi. Meskipun demikian mereka umumnya hanya beternak secara individu dengan kandang-kandang pribadi di rumah masing-masing. Pembangunan kandang sapi komunal dilakukan untuk memfasilitasi kebutuhan bersama masyarakat mengoptimalkan keuntungan beternak sapi karena selain pertimbangan kesehatan karena tempatnya yang terpisah dari pemukiman penduduk, pembuatan kandang sapi komunal juga memungkinkan sapi-sapi dapat berkembang biak dengan cepat dibandingkan model konvensional.

Kandang sapi komunal berukuran lebih besar dari kandang sapi biasa. Kandang tersebut umumnya memiliki 10 ruang persegi yang setiap kotaknya bisa ditempati 5 - 10 ekor sapi. Kandang komunal ini tidak dilengkapi dengan pasak-pasak untuk mengikat sapi sehingga sapi dipelihara dengan bebas, lebih leluasa bergerak dan merasa nyaman. Sistem pengembangan kandang sapi komunal juga mengedepankan asupan nutrisi sesuai dengan target peternakan baik penggemukan maupun pembibitan. Perbaikan nutrisi dimulai dengan pemberian berbagai jenis pakan mulai dari pakan. Kandang komunal juga dilengkapi dengan gudang pakan untuk tempat menyimpan pakan ternak serta rumah kompos sebagai tempat untuk pengolahan limbah kotoran sapi (YGSI, 2019).

Pembangunan kandang sapi komunal dilakukan untuk mendukung penyediaan fasilitas publik dalam rangka pengembangan usaha desa Ponjong. Desa Ponjong memiliki area persawahan cukup luas dan limbah jerami dari persawahan itu dapat dipasok untuk pakan sapi-sapi di peternakan komunal. Sementara peternakan sapi bisa mendukung pertanian desa dengan limbah kotoran sapi yang bisa dipakai sebagai pupuk. Dengan demikian menindaklanjuti pembangunan kandang komunal sebagai merupakan awalan agribisnis yang nantinya bisa dikembangkan lebih jauh lagi.

Optimalisasi fungsi pembangunan kandang sapi dilakukan dengan cara memberikan transfer ilmu pengetahuan berupa pelatihan kepada penggaduh mengenai cara perawatan sapi, pengecekan kondisi kesehatan sapi, dan perbaikan beberapa bagian kandang yang kurang baik. Ahli sapi dari Korea Selatan secara rutin mengunjungi dan memberikan pelatihan mengelola kandang sapi komunal (Laporan berkala Pembentukan Desa Percontohan Saemaul bulan Maret-Mei, 2016). Peran mereka adalah membuat perawatan sapi di kandang lebih tersistem dengan menyisipkan pengetahuan peternakan dari Korea Selatan. Kendati demikian tanpa mengubah komponennya, praktek pemeliharaan sapi dengan sistem Korea Selatan tetap harus menyesuaikan dengan kondisi alam Gunung Kidul.

Pengembangan fasilitas publik yang berikutnya adalah pembangunan gedung pertemuan. Pembangunan Gedung pertemuan dilakukan dalam rangka menyediakan tempat bagi warga desa berkumpul dan membahas rencana program kerja desa. Sebelumnya pertemuan desa banyak dilakukan di rumah-rumah warga. Pembangunan Gedung pertemuan juga ditujukan untuk memberikan pemasukan bagi kas desa dengan cara disewakan kepada publik. Semua pihak berpartisipasi dalam pembangunan gedung. Pemerintah Gyeongsangbukdo menyediakan dana untuk pembangunan gedung sedangkan pemerintah daerah Yogyakarta memfasilitasi komunikasi antara pemerintah Gyeongsangbukdo dengan 
masyarakat. Masyarakat juga berperan untuk menyiapkan material yang diperlukan seperti pasir, bambu, tenaga kerja maupun logistik. Pengurus desa bertanggungjawab pada pengurusan izin penggunaan lahan, pembuatan gambar desain gedung, dan pengurugan sedangkan Bumdes berperan membuat pedoman penggunaan Gedung serta mengelola penggunaan Gedung (Wawancara Anwari, 29 Januari 2019). Gedung pertemuan tersebut diberi nama Saemaul Undong. Gedung tersebut selanjutnya dipergunakan bagi masyarakat untuk berkumpul membahas program pengembangan unit usaha desa.

Upaya implementasi kerja sama Yogyakarta-Gyeongsangbukdo tersebut diatas saling bersinergi dan berkait untuk mencapai tujuan akhir meningkatkan kemandirian dalam memenuhi kebutuhan warga. Revolusi mental melalui semangat gotong royong, ketekunan serta kerja keras sesama masyarakat dalam kerangka Saemaul Undong memberikan inspirasi bagi desa Ponjong untuk juga menerapkan nilai-nilai tersebut untuk menciptakan lingkungan fisik, sosial dan kesejahteraan yang lebih baik. Hal tersebut tercermin dalam respon positif masyarakat dalam mengembangkan peternakan sapi sistem komunal. Dari pengembangan peternakan sapi komunal tersebut maka diharapkan nilai-nilai positif kearifan lokal dapat mengalir ke program-program desa yang lain.

Terkait dalam upaya pengentasan kemiskinan maka kerja sama internasional DIYGyeongsangbukdo memiliki desain rencana pengembangan desa organik. Selain mengelola pupuk kompos dari limbah sapi, masyarakat desa, tim dari pemerintah Gyeongsangbukdo, dan pemerintah daerah Yogyakarta mengembangkan rencana jangka panjang untuk kandang sapi komunal. Desa Ponjong akan mengintegrasikan kandang komunal sebagai wisata peternakan dengan area wisata Waterbyur. Para wisatawan nantinya diharapkan bisa menikmati agrowisata di sekitar area Waterbyur dan bisa mengunjungi area peternakan kandang komunal sambal menunggu anak-anak mereka bermain di lokasi wisata. Selain area peternakan juga disediakan area pertanian sehingga ibu-ibu ibu dapat memanfaatkan waktu untuk membeli sayuran yang disediakan di lokasi wisata sambal menunggu anak-anak bermain. Dengan demikian pengembangan peternakan sapi komunal akan mendukung pengembangan pariwisata desa.

Kerja sama pengembangan pengembangan peternakan sapi komunal ini merupakan salah satu upaya mendukung pembangunan berkelanjutan. Dalam konteks pembangunan global yang berkelanjutan maka kerja sama internasional Yogyakarta-Gyeongsangbukdo ini merupakan salah satu aktifitas lokal pencapaian agenda global dari bawah ke atas atau biasa disebut dengan the achievement of the global agendas from the bottom-up (UCLG dalam https://issuu.com/uclgcglu/docs/uclg-sdgs guide-2nd versionaaff-interactivo). Melalui transfer pengetahuan mengenai nilai-nilai gotong royong, kerja keras serta disiplin maka masyarakat terinspirasi untuk meningkatkan kemandirian dalam mengembangkan unit usaha dengan jalan pemberdayaan masyarakat. Penyediaan fasilitas publik berupa bantuan pembangunan gedung serbaguna serta pengembangan peternakan sapi komunal semakin mempermudah masyarakat memperoleh akses bagi pemenuhan kebutuhannya. Diharapkan upaya ini akan memudahkan jalan menuju peningkatan kesejahteraan masyarakat desa juga sekaligus menguatkan julukan Kabupaten Gunungkidul 
sebagai gudang ternak dan gudang padi. Dengan demikian kegiatan ini dapat memberikan inspirasi bagi daerah-daerah lain di Indonesia untuk mengoptimalkan kerja daerah internasional daerah dalam mengentaskan kemiskinan.

\section{SIMPULAN}

Implementasi pembangunan berkelanjutan melalui pengentasan kemiskinan bisa diawali dari tingkat lokal. Keberadaan pemerintah daerah memiliki peran kunci dalam mendukung upaya tersebut. Kerja sama internasional daerah dalam hal ini menjadi salah satu sarana pendukung mengatasi kemiskinan dengan mensinergikan pemerintah daerah masyarakat dan dan mitra luar negeri.

Kerja sama internasional Yogyakarta-Gyeongsangbukdo merupakan salah satu implementasi kerja sama internasioanal yang berfokus pada pengentasan kemiskinan melalui pembangunan daerah pedesaan. Melalui transfer ilmu pengetahuan berupa nilai-nilai lokal seperti disiplin, kerja keras dan gotong royong, masyarakat desa bergerak membangun unit usaha desa melalui pemberdayaan masyarakat. Disisi lain, pengembangan pelayanan publik berupa pembangunan gedung guna dan pembuatan kandang sapi komunal mempermudah akses masyarakat dalam mengembangkan unit usaha sekaligus meningkatkan kemandirian dan kesejahteraan. Sebagai penutup artikel ini memberikan saran bagi pemerintah daerah di Indonesia untuk juga membuka diri mencari jalan mengembangkan jejaring kerja sama untuk memenuhi kebutuhan domestik daerah. Selain itu pelibatan masyarakat sebagai salah satu agen penting dalam kerja sama internasional akan bermanfaat dalam meringankan tanggung jawab pemerintah daerah dalam menjalankan program kerja. Untuk pengembangan riset selanjutnya dapat difokuskan pada eksplorasi partisipasi masyarakat dalam mendukung kerja sama internasional daerah mengatasi kemiskinan dalam kerangka pembangunan berkelanjutan.

\section{DAFTAR PUSTAKA}

Buku, artikel jurnal, e-book

Andrews, C. W. (2004). Anti-Poverty Policies in Brazil: Reviewing the Past Ten Years. International Review of Administrative Sciences, 70(3), 477-488. https://doi.org/10.1177/0020852304046202

Anwar, R. P. 2017. Reflection of Saemaul Undong Movement in Indonesia. Saemaul Movement dan Community Studies House. https://www.researchgate.net/ publication/316283495 L accessed March 8, 2019.

Ariadi, K. (2000). Paradiplomasi, Otonomi Daerah, dan Hubungan Luar Negeri. Perencanaan Pembangunan, 21, 50-61.

Bamberger M. (1986). The Role of Community Participation in Development Planning. Washington, D.C.

Barber, B.R. (2013). If Mayors Ruled the World, Dysfunctional Nations, Rising Cities, New Haven: Yale University Press,

Cohen, J. M., \& Uphoff, N. T. (1980). Participation's Place in Rural Development: Seeking Clarity through Specificity. World Development, 8(3), 213-235. https://doi.org/10.1016/0305-750X(80)90011-X

Douglass, M. (2013). The Saemaul Undong: South Korea's Rural Development Miracle in Historical Perspective, Asia Research Institute, Working Paper Series No. 197. 
Lancaster, C. (1390). Foreign Aid; Diplomacy, Development, Domestic Politics. Chicago and London: The University of Chicago Press.

Jain, P. (2005). Japan's Subnational Governments in International Affairs. New York: Routledge.

Mubangizi, B. C. (2009). Poverty Alleviation and Service Delivery- Developing A Conceptual Framework for South Africa' s Service Delivery System. International NGO Journal, 4(10), 446-455.

Noor, M. (2012) Memahami Desentralisasi Indonesia. Yogyakarta: Interpena

Panuluh, S., \& Fitri, M. R. (2016). Perkembangan Pelaksanaan Sustainable Development Goals (SDGs) di Indonesia. Biefing Paper 02 (Vol. infid). Retrieved from http://www.sdg2030indonesia.org/ancomponent/media/upload-book/Briefing_paper_No_1_SDGS_-2016-Meila_Sekar.pdf

PSTS UGM Saemaul Globalization Foundation Memberdayakan Masyarakat Gunung Kidul. (2016). Retrieved March 8, 2019, from https://ugm.ac.id/id/berita/11603saemaul.undong.jadi.contoh.strategi.pembangunan.pedesaan

Reed, Edward P. (2010) Latin Is Saemaul Undong a Model for Developing Countries Today?, International Symposium in Commemoration of the 40th Anniversary of Saemaul Undong Hosted by the Korea Saemaul Undong Center September 30.

Setiawati, N. A. (2015). Implementasi Saemaul Undong dan Pembangunannya di Era Globalisasi. In The Implementation of Trisakti and Saemaul Undong in the Improvement of Social Welfare (p. 51). Yogyakarta: Pusat Studi Tri Sakti dan Saemaul Undong.

Sumner, A., \& Mallett, R. (2012). The Future of Freign Aid: Development Cooperation and The New Geography of Global Poverty. The Future of Foreign Aid: Development Cooperation and the New Geography of Global Poverty (1st ed.). Nnew York): Palgrave Macmillan. https://doi.org/10.1057/9781137298881

Swastika, D. K. S., \& Supriyatna, Y. (2016). The Characteristics of Poverty and Its Alleviation in Indonesia. Forum Penelitian Agro Ekonomi, 26(2), 103. https://doi.org/10.21082/fae.v26n2.2008.103-115

Trivelli, C., Yancari, J., \& De los Ríos, C. (2009). Crisi and Rural Poverty in Latin America (No.37). Rural Territorial Dynamics Program (Vol.1). Santiago,Chile. https://doi.org/10.1017/CBO9781107415324.004

\section{Dokumen dan Report}

BKPM DIY, Monitoring dan Evaluasi Kerja sama Pemerintah Provinsi DIY tahun anggaran 2017, Yogyakarta: BKPM.

Laporan berkala Pembentukan Desa Percontohan Saemaul bulan Desember 2015-Februari. 2016. Saemaul Globalization Foundation. Yogyakarta.

Laporan berkala Pembentukan Desa Percontohan Saemaul bulan Maret-Mei, 2016. Saemaul Globalization Foundation. Yogyakarta.

Laporan Berkala Pembentukan Desa Percontohan Saemaul bulan Januari-Maret, 2017. Saemaul Globalization Foundation. Yogyakarta.

Laporan Berkala Pembentukan Desa Percontohan Saemaul bulan Maret-Juni 2018. Saemaul Globalization Foundation. Yogyakarta.

United Nations. (n.d) Transforming Our World: The 2030 Agenda for Sustainable Development dalam https://sustainabledevelopment.un.org/post2015/ transformingourworld.

Yayasan Globalisasi Saemaul Indonesia. 2019. Menyemai Asa Menuai Sejahtera bersama Saemaul Undong [Seeding Hopes Reaping Prosperity]. Yogyakarta: YGSI.

\section{Website}

cnnindonesia.com. (2017) Sri Mulyani Keluhkan Pemda Terlalu Bergantung pada APBN https://www.cnnindonesia.com/ekonomi/20171206135433-532-260497/sri-mulyani-keluhkanpemda-terlalu-bergantung-pada-apbn akses tanggal 5 April 2020).

$\begin{array}{llll}\text { Bappeda. infografik } & \text { pengentasan dalam }\end{array}$ http://bappeda.jogjaprov.go.id/dataku/infografik/kemiskinan). 
Deputi Menteri PPN/Kepala Bappenas Bidang Kependudukan dan Ketenagakerjaan, 2017.

Jogjaprov. DIY Masuk Tiga Besar Daerah Siap SDGs dalam https://jogjaprov.go.id/berita/detail/8045-diymasuk-tiga-besar-daerah-siap-sdgs akses tanggal 29 Juli 2020

Kompas. Mendagri Minta Pemda Tak Bergantung pada Bantuan Dana dari Pusat", (2020) dalam https://nasional.kompas.com/read/2020/03/04/20595721/ mendagri-minta-pemda-takbergantung-pada-bantuan-dana-dari-pusat akses tanggal 4 April 2020).

Kompas. "Mendagri Minta Pemda Tak Bergantung pada Bantuan Dana dari Pusat ", dalam https://nasional.kompas.com/read/2020/03/04/20595721/2 mendagri-minta-pemda-takbergantung-pada-bantuan-dana-dari-pusat akses tanggal 4 April 2020).

Universitas Gadjah Mada. 2016. Saemaul Undong jadi Contoh Strategi pembangunan Desa. https://ugm.ac.id/id/berita/11603-saemaul.undong.jadi.contoh.strategi.pembangunan. pedesaan, akses 11 Februari, 2019.

Universitas Gadjah Mada. Saemaul Undong Jadi Contoh Strategi Pembangunan Pedesaan dalam https://ugm.ac.id/id/berita/11603-saemaul.undong.jadi.contoh.strategi. pembangunan.pedesaan akses tanggal 11 Februari 2018.

Universitas Gadjah Mada. UGM, DIY, dan Gyeongsangbuk-do Jalin Kerja Sama dalam https://ugm.ac.id/id/berita/9435-ugm.diy.dan.gyeongsangbuk-do.jalin.kerja.sama akses tanggal 8 Maret 2019.

https://sustainabledevelopment.un.org/processes/post2015/owg/documents.

Profil Potensi Desa Ponjong, https://www.ponjong.desa.id/first/artikel/59 akses tanggal 5 April 2020.

UCLG. Fostering A Localization Movement; Promoting the accomplishment of the 2030 Agenda from the bottom up dalam https://issuu.com/uclgcglu/docs/uclg-sdgs guide-2nd version-aaff-interactivo akses tanggal 5 April 2020.

UCLG And Local Government. (n.y). Pembangunan Berkelanjutan Tujuan yang Perlu Diketahui Oleh Pemerintah Daerah dalam https://issuu.com/uclgcglu/docs/tujuan-sdgs akses tanggal 4 April 2020.

\section{Wawancara}

Pradipta, N, Ketua YGSI (Yayasan Global Saemaul Indonesia) tanggal 29 Januari 2019.

Setiono, C.C., Subdivisi Kerja sama Luar Negeri, BKPM DIY tanggal 17 Desember 2018,

Anwari, S. Kepala Subdivisi Penguatan of Potensi Masyarakat BPPM DIY tanggal 29 Januari 2019. 